\title{
Linking Talent Management to Traditional and Boundaryless Career Orientations: Research Propositions and Future Directions
}

\author{
Marian Crowley-Henry, ${ }^{1}$ Emily T. Benson ${ }^{2}$ and Akram Al Ariss ${ }^{3}$ \\ ${ }^{1}$ Maynooth University, Maynooth, Co Kildare, Ireland \\ ${ }^{2}$ Department of Business Management, Keene State College, Keene, NH, USA \\ ${ }^{3}$ Toulouse Business School, Toulouse, France
}

\begin{abstract}
Talent management (TM) is a growing field that concentrates on optimizing human resources so that they provide a sustained competitive advantage to organizations. While successful TM practices are widely understood to include career development, the topics of careers and TM remain largely disconnected in the human resource management (HRM) literature. In this conceptual paper, we review the traditional and boundaryless career literature from a multi-level perspective, in order to theoretically develop TM, which to date has been consistently described as under-theorized. We contend that consideration of the functioning of careers within and across individual, network, organization, industry, occupation, and national/global structures is important when developing effective TM practices. To further understand the relationship between careers and TM, this paper develops researchable propositions for future studies, supported by the existing literature.
\end{abstract}

Keywords: talent management; career; career development; traditional career; boundaryless career; multi-level

\section{Introduction}

Talent management (TM) is a topic of increasing academic interest (De Boeck et al., 2018; McDonnell et al., 2017) despite persistent claims of conceptual ambiguity (Lewis and Heckman, 2006; Meyers et al., 2013; Vaiman and Collings, 2013; Dries, 2013a; Festing and Schäfer, 2014) and under-theorization (GallardoGallardo et al., 2013, 2015; Thunnissen et al., 2013; Gallardo-Gallardo and Thunnissen, 2016). To develop TM from its practitioner genesis (Michaels et al., 2001) and move towards a theorization of TM, some researchers link TM with research on international mobility (for example, Al Ariss et al., 2014; Cerdin and Brewster, 2014; Collings, 2014; Crowley-Henry and Al Ariss, 2016); others with research on careers (for example, Carr et al., 2005; Iles et al., 2010; Dries et al., 2012; De Vos and Dries, 2013). However, a comprehensive analysis linking the relational structures affecting careers (Al Ariss and Syed, 2011) to TM has not yet been performed. This

Correspondence: Marian Crowley-Henry, Maynooth University, National University of Ireland, Maynooth, Maynooth, Co Kildare, Ireland.Tel.: +35317084756 E-mail marian.crowleyhenry@mu.ie paper concentrates on this particular research gap. Building on multi-level career literature concerning the traditional and boundaryless career orientations, it offers researchable propositions linking the relational structures of careers to TM. A better understanding of the roles of different structures and actors within and across the career eco system, including the individual, network, organization, industry, occupation, and country levels, will aid the development of TM strategies and practices in organizations and encourage the advancement of theoretical links between career theory and TM.

TM describes an organization's identification of key positions and, subsequently, the development and retention of a talent pool to fill those positions (Collings and Mellahi, 2009; Thunnissen et al., 2013). TM is increasingly important to organizational leaders who are attempting to maximize their business performance, with the central assumption that it is essential to recruit, develop, and retain 'top' employees in order to meet the strategic business objectives of organizations (Tung, 2016; De Boeck et al., 2018). As Dries et al. (2012) explain, however, assumptions about the best ways to manage internal talent can conflict with contemporary patterns of 'boundaryless' careers (Arthur, 1994; Bird, 
1994). In this case, TM practices that focus on recruiting, developing and/or retaining talent may be wasted efforts for those individuals following a 'boundaryless' career path, as they are likely to change organization or occupation. We argue that in order to attract, develop and retain key employees in organizations (that is, 'talent'), it is important to understand the nature and context of their careers. This paper builds on previous research on TM and careers (Dries et al., 2012; Walsh et al., 2016). By focusing on the recognized career concepts of the traditional and boundaryless career, our goal is to help organizational researchers to better elucidate the process of TM. In order to do so, this paper presents propositions developed from the literature for facilitating future empirical research and testing how TM practices can best be employed in relation to different career structures. We outline the following career structures which individually and collectively affect TM practices: individual, group/network, organization, industry/occupation, and national/global. Figure 1 presents a framework of the multi-level and relational career factors influencing TM practice decisions that we unpack in this paper. De Boeck et al. (2018: 211) declare that 'If we want to understand the effects of talent philosophies, TM objectives, degree of workforce differentiation, and the TM system [which they position at the management/organization level, see page 3 of their article] and how these trickle down into perceived TM practices, talent status, and individual employee reactions [at the individual level, see page 3 of their article], finally amounting into group-level and organizational-level effects in terms of organizational performance ... we need multilevel studies'. This paper attempts to perform such a multi-level analysis by referring to existing literatures on careers and drawing theoretical implications relevant to TM literature.

TM is a complex phenomenon, which can be explored at different levels, each with different concerns (Dries, 2013b; Crowley-Henry and Al Ariss, 2016; De Boeck et al., 2018), and with different outcomes of the intended, actual and perceived (Wright and Snell, 1998; Wright and Nishii, 2006) TM practices (Gelens et al., 2013, 2014; O'Connor and Crowley-Henry, 2017). Crowley-Henry and Al Ariss (2016) have put forward five main concepts of TM in the contemporary literature, which range from $\mathrm{TM}$ as synonymous with human resource management to TM specializing in human resource development (HRM). Similarly, Dries (2013b) presents six different theoretical perspectives on talent, showing the variation of focus across academic disciplines. This variation manifests in conceptual ambiguity and reluctance to directly theorize TM as a single phenomenon. Rather, $\mathrm{TM}$ can have a different nuance in meaning for different authors, both practitioner and academics (Dries, 2013b). With this in mind, our focus in this paper is not to offer a definitive conceptualization of TM, but rather to suggest how a multi-level career lens can help to better understand and theorize TM.

While there are HRM studies that call for a 'best fit' approach, suggesting a need to fit HRM practices and understanding to the particular circumstances of the organization, industry, and/or local country/region (Delery and Doty, 1996; Brewster, 1999; Brewster and Bennett, 2010), career studies that adopt such a tailored comprehensive perspective have been, until recently, rather scarce (Khapova and Arthur, 2011). Research has made it clear, however, that organizations need to be cognizant of the structures affecting career choices and to adapt their human resource practices, such as TM, accordingly (Chen et al., 2011). Although the influence on careers of individual, group/network, organization, industry/occupation, and national/global structures overlap and are relational ( $\mathrm{Al}$ Ariss and Syed, 2011), for clarity of purposes we present them separately while also acknowledging their many intersections (see Figure 1). Our paper contributes to the management and organizational research on careers and TM in two critical ways. First, it sketches a comprehensive

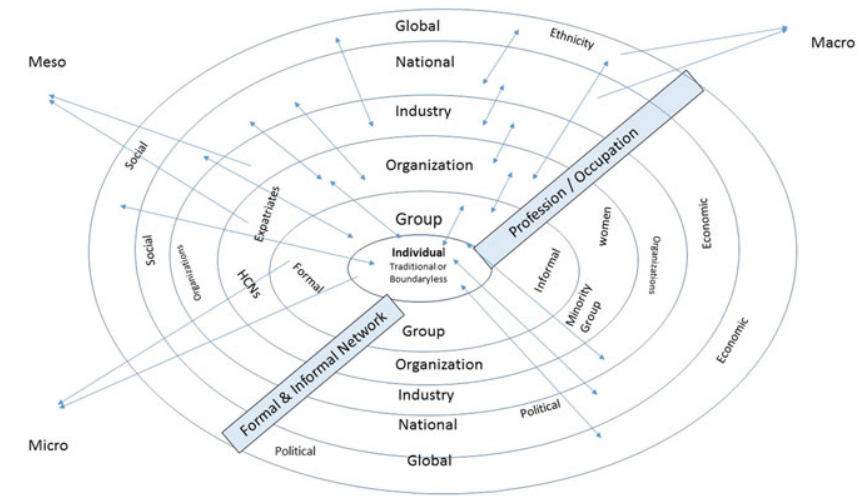

Figure 1 Multi-level and relational career factors influencing TM practice decisions. [Colour figure can be viewed at wileyonlinelibrary.com] 
literature review of what is currently known about the different structures affecting careers at and across different levels. Second, it draws implications for TM and offers researchable propositions to provide scholars with directions for future research.

\section{Research propositions}

In this section, we discuss careers at the individual, group/network, organization, industry/occupation, and national/global levels. Each of these levels may be considered in isolation while also recognizing that they are permeable and overlap in practice (see Figure 1). We connect the corresponding literature and research to the existing understandings of TM. Propositions are developed that will assist the management of talents (those identified as possessing the human capital best matched to key positions) in organizations in a more effective way.

\section{The individual level}

Several trends emerge from the research on individuals' careers (at the level of the individual actor influencing career choices and outcomes). First, a dominant research line has focused on the rise of career concepts such as the boundaryless career (see Arthur, 1994; Gunz et al., 2011; Inkson et al., 2012). Boundaryless careers are defined as being managed by individuals rather than organizations, characterized by crossing organizational and national boundaries, and fraught with higher job uncertainty (Littleton et al., 2000; Fuller and Marler, 2009; Sullivan and Baruch, 2009; Baruch and Vardi, 2016). This approach assumes that along with the stress of less stability, individuals are now freer to make professional choices that work for them rather than for their employers. However, other research perspectives indicate that many careers still remain more under the control of organizations than individuals (Dany, 2003). Indeed, Dries et al. (2012: 271) argue that employees "who organizations consider their "best" people are more often found in traditional-organizational careers', suggesting that individual-focused career concepts such as the boundaryless career do not fit with TM and that empirical research does not support a widespread shift from the individually preferred traditional career paths within organizations. It may be that boundaryless careers, as these have been conceptualized, best describe the careers of certain individuals possessing easily transferrable skills that are in high demand who perhaps are motivated to move organization in furtherance of their career, while traditional careers - careers within the same organization - remain both the dominant model and the preferred employment model for most individuals (Hassard et al., 2012; Inkson et al., 2012). Recent research suggests that talent management approaches need to be more balanced between organisational needs and that they should be more closely linked with the individual's goals and expectations in order to retain high potential talent (Farndale et al., 2014). We argue that TM, concerned with the attraction, development and retention of employees whose skills are valued for key organizational positions, needs to consider employees with boundaryless career mindsets as well as employees with a preference for traditional organizational career paths, in order to best manage all of these talents.

Boundaryless careers have been connected to global economic changes (Bird, 1994; Arthur and Rousseau, 1996; Littleton et al., 2000) and increasing international mobility (Dickmann and Cerdin, 2014). As people move across multiple organizations and geographic settings (Bozionelos, 2004), individuals engaging in more boundaryless careers must manage their own careers by capitalizing on their skills and knowledge (Bird, 1994; Judge and Kammeyer-Mueller, 2011; Converse et al., 2012). As they build their careers, individuals gain 'career capital', which is critical to the career development of boundaryless careers (DeFillippi and Arthur, 1994, 1998). Research has also indicated that individuals engaging in boundaryless careers have distinct career attitudes. For example, they show less organizational commitment (Enache et al., 2013), and prefer their subjective satisfaction and work-life balance to elements such as pay and promotion outcomes, as well as high occupational status (Lyons et al., 2012). Other studies focus on the impact of the psychological contract (the implicit non-written contract based on the expectations of the worker and employer (Argyris, 1960; Levinson et al., 1962)) on the career of individuals. Sullivan and Emerson (2000) put forward three changes in the transition from an organizational career to a boundary-less career orientation. These are a shift in the individual's focus from extrinsic to intrinsic rewards, a move towards professional loyalty instead of organizational loyalty, and a move towards self-reliance.

For organizations, understanding the differences in goals and motivations between those employees on boundaryless career paths versus traditional career paths is imperative. For many employees, it is difficult to have a flexible, constantly shifting career, and it may be that many 'boundaryless' careers are merely stepping stones on the way to stability. For example, citing research by Dries and Pepermans (2008), Dickmann et al. (2016) highlight the fact that high potential employees continue to expect more traditional career options demonstrated in high upward mobility and low inter-organizational mobility. Similarly, research into part-time work indicates that many employees are more satisfied with part-time positions that have a strong chance of leading to full-time 
employment (Clinton et al., 2011). Furthermore, older workers and those who desire stability may not prefer to follow a boundaryless career path or change employer, but they may be forced to because of corporate downsizing or other destabilizing factors (Thornhill and Saunders, 1998; Reitman and Schneer, 2005; Currie et al., 2006; Goldman, 2011; Lyons et al., 2012).

Organizational leaders implement TM practices, such as designated leadership development programs or a steeper reward management system for their recognized talents, to most effectively leverage their human capital (Cascio and Boudreau, 2016) by either enticing talent to join the organization, to develop their potential and performance within the organization, and/or to remain with the organization. TM practices that reflect the reality that individual careers are complex and varied are likely to be more successful than TM practices that try to be generic or all-encompassing. As discussed in this section, employees tend to follow, voluntarily or involuntarily, one of two distinct overarching individual career orientations: traditional or boundaryless. Given this line of argument, employees may be motivated by more subjective (e.g., independence for those with a boundaryless career orientation) or objective (e.g., a more senior organizational position for those with a traditional career orientation) individual perceptions of career success. In addition, career motivations are not static and may change over time and circumstance. The greater the understanding organizational leaders have of the individual career orientations of their employees, and of their motivations for following these career paths, the more successful their TM practices will be in meeting the objectives of TM (to attract, develop and retain key employees; Collings and Mellahi, 2009). This leads to our first proposition concerning the individual structure of careers and the corresponding implications for TM:

Proposition 1. Talent management practices should be flexibly tailored (e.g., moderating between intrinsic and extrinsic rewards) to traditional and boundaryless career orientations, cognizant that individual career orientations can differ and potentially change over time.
This proposition could be empirically tested by surveying employees in organizational talent pools about their career motivations and preferences in terms of lateral and vertical mobility within the same organizational group, across the same organization, spread geographically, and across different organizations. The resultant data could be analyzed against the various indices of the respondents' recruitment patterns (e.g., date and circumstances of their recruitment), performance management (e.g., post a talent-targeted training/development program) and retention parameters.

\section{The group/network level}

Research on the group/network level and careers is focused primarily on formal and informal groups within organizations and new emerging social structures such as professional networks (Currie et al., 2006). We depict and differentiate between group and network levels in Figure 1. We position the group level within a fixed organizational context, while the network level can transcend a particular group, organization, industry, nation and global domain. There is a formal and informal component to both the group and network levels. Table 1 provides examples across formal/informal groups and networks.

This pattern of research is consistent with the notion of boundaryless careers insofar as it emphasizes the decreasing centrality of the organization in career development. The dominant theme in this literature is that developing personal contacts and relationships both within organizations and outside of formal organizational groups is critical for individual career success (Dansky, 1996; Oh et al., 2006).

Manolopoulos et al. (2011) focus on formal organizational groups and career success in specialized research and development (R\&D) units within multinational corporations (MNCs). They found that these highly specialized knowledge professionals develop their career bases by working in intense group environments. While these groups were created by the organization, because of their high-status functions, they behave almost as if they were external to their organization. These groups profoundly shape the career preferences and career

Table 1 Internal groups and external networks: formal and informal structures

\begin{tabular}{|c|c|c|c|}
\hline Groups - internal & Example & Networks - external & Example \\
\hline Formal & $\begin{array}{l}\text { Work group/department or project team with } \\
\text { specific aims or deliverables relevant to the } \\
\text { individual's work role in the organization }\end{array}$ & Formal & $\begin{array}{l}\text { Member of independent professional organization } \\
\text { (e.g. CIPD for HR directors), work-related but } \\
\text { not organization-specific }\end{array}$ \\
\hline Informal & $\begin{array}{l}\text { Social group within the organizational context, } \\
\text { such as a particular club or society } \\
\text { (e.g. informal Christmas party committee; } \\
\text { organization golf society; organization gym) }\end{array}$ & Informal & $\begin{array}{l}\text { Member of independent social organization } \\
\text { (e.g. golf club), non-work related }\end{array}$ \\
\hline
\end{tabular}


development paths of the members (Manolopoulos et al., 2011). By providing resources such as advice, instruction, and assistance, coworkers can help reduce employee role ambiguity, conflict, and overload (Chiaburu and Harrison, 2008).

Lawrence (2011) finds that individuals compare themselves to others across various groups in their organizations when considering their career development. These across-group comparisons have noticeable effects on the ultimate career satisfaction of individuals (Lawrence, 2006, 2011). Other studies show that networking within one's own organization can enhance that individual's reputation (Steward et al., 2010) leading to higher status and feelings of career success (Forret and Dougherty, 2004).

While our review of careers and groups revealed that mentoring relationships outside of traditional organizational contexts are becoming more important, we also came across a number of papers that consider individual careers and mentoring relationships within organizations. Koberg et al. (1994), for example, found that mentoring increased as protégés moved up in organizational rank. Furthermore, they found that group effectiveness, as well as job satisfaction, are related to mentoring relationships. Dawley et al. (2010) found that organizations, as well as individuals and their careers, benefit from formal mentoring relationships. Their work identified mentoring as a moderator in the context of perceived organizational support, supervisor support, job fit, and turnover intentions.

In addition to work groups, professional networks that are external to individuals' organizations emerge as important to career. Networking is seen as a critical factor in career development, as it is positively related to several career-related variables such as performance, motivation, career goals, mentoring, organizational mobility, salary, promotions, and career satisfaction (Wolff and Moser, 2009). Friedman et al. (1998) suggest that members of professional networks have more career optimism than non-members. This can be ascribed to the fact that professional networking behaviors provide access to useful non-redundant sources of information, such as best practices and business trends (Chang, 2005). Research has also found that formal professional networks may generate mentoring relationships, which can lead to positive career outcomes (Dansky, 1996; Allen et al., 1997). Bagdadli et al. (2003) discuss how professional networks are based on colleague or client relationships, while personal networks are based on friend or family relationships. They found that both can be critical in access to career growth. One study carried out by Claussen et al. (2014) empirically established that a manager's network size has a positive effect on his or her likelihood of being promoted to a middle management position.
According to Grote and Hall (2013), the social contexts of careers are complex and extend across groups, families (see also Patton et al., 2014), and society at large, which may result in multiple personal identities that are molded and changed over time. They highlight the interconnected and relational nature of career, which we illustrate in this paper and depict in Figure 1.

There is no denying to the fact that workplace is a (potentially) rich source of learning (Billett, 2001; Streumer, 2006). Social networks are perceived to be crucial carriers of workplace learning (Storberg, 2002; Kessels and Poell, 2004). On one hand, social networks can enhance the opportunities for talented employees to develop their competencies on the job, by augmenting the learning potential inherent in their work (Ellström, 2001; Tjepkema, 2003). On the other hand, they are important carriers of employee knowledge, embedded in their cultural and structural characteristics (Poell and Van der Krogt, 2002).

While there is significant research pertaining to networking and individual learning and career growth, this level is under-explored in the context of attracting, developing and retaining human capital in organizations' TM practices. As groups and networks are critical contemporary career structures, TM practices should take into account the group/network influence over career decisions and orientations. In sum, the group and network structure can be formal or informal as well as internal or external (see Table 1). Based on the above discussion, we propose the following:

Proposition 2a. TM practices should leverage on the formal and informal internal group association of its employees as it facilitates the information-gathering and socialization of prospective and existing 'talent', and de facto, in attracting, developing and retaining talent to and within organizations.

Proposition 2b. TM practices should leverage on the formal and informal external network association of its employees as it facilitates the expectations and comparison processing of organizational contexts of prospective and existing 'talent', and de facto, in attracting, developing and retaining talent to, within and across organizations.

These group-/network-level propositions are relevant for organizations that, through their TM practices, seek to attract, develop and retain talented employees in key organizational positions. The influence of group and network structures at their respective levels (see Figure 1 ) on talented employees' decisions to join, grow and remain in a particular organization requires further exploration and empirical research. Bird (1994) argues that careers are repositories of knowledge. We contend 
that individual careers are informed and made knowledgeable of alternatives through groups and networks, both informal and formal, with influence ... most obvious at the intersection of individual autonomy, group interaction and organization structure and values' (Bird, 1994: 337).

\section{The organization level}

Research on TM and careers shows that organizational leaders are interested in reducing the turnover of 'talent' and in providing career support (Carr et al., 2005; De Vos and Dries, 2013), but the boundaryless career orientation poses a significant challenge to organizations attempting to retain knowledge and talent (Currie et al., 2006). Furthermore, many individuals are still interested in stable, traditional careers (Hassard et al., 2012; Inkson et al., 2012). Research focused on identifying factors that reduce turnover include Reiche's (2009) study, which examined organization-level factors in MNCs in Singapore, including organizational structure and practices and their relationship to individual turnover intentions. One of the findings was that career planning for host country nationals $(\mathrm{HCN})$ is as critical for MNC managers as career planning for expatriate workers. Research conducted by Hay Group in 2001 found that the majority of the employees chose career opportunities, learning and development as the foremost reasons to stay in an organization. Reiche et al. (2011) found that perceived career prospects within an organization are critical for the retention of international assignees in MNCs. Those perceived prospects helped 'inpatriates' (i.e., host country nationals (HCNs) sent to headquarters) to integrate within organizations. Their study exemplifies the complex overlapping and interrelationship between individual, organization, national (e.g., HCNs) and global factors (e.g., international assignees across MNC subsidiary locations) levels in career studies (see Figure 1).

In terms of managing talents in organizations, Eddleston (2009) found that an organizational climate that encourages employees to compare themselves to others who are more advanced in their careers decreases turnover intentions and increases career satisfaction, benefiting both organizations and individuals. This links with the previous section at the group/network level, where crossgroup/network career comparisons may be facilitated through organizational structure and climate.

A major theme discussed in the literature highlights the benefits that both organizations and individuals can derive from stable career paths within single organizations and recognizes that boundaryless careers may not be desirable from the viewpoints of some organizations. This is particularly pertinent for TM, where the organizational aim is to attract, develop and retain talents for key organizational positions at present and in the future (Collings and Mellahi, 2009). The focus in this body of career research is on reducing turnover, encouraging career planning within organizations, and promoting organizational climates, policies, and programs such as mentoring programs that support careers. It is likely that TM practices that actively support the career development needs of employees will aid organizations to attract talent, reduce turnover and increase retention of employees in identified talent pools. The literature here leads to the following proposition:

Proposition 3a. Organization-level career development plans, opportunities and supports strategically tailored for high potential employees demonstrating boundaryless (e.g., lateral, vertical or international mobility preferences) and traditional (e.g., vertical mobility preferences) career orientations will reduce turn-over intentions and thereby facilitate the performance development and retention of talent within the organization.

This proposition underlines the importance of organization-level involvement in the career development of the talent pool within the organization. While career development is mostly perceived to be the individual employee's own responsibility, failure on the part of the organization to account for boundaryless career oriented talent, may result in an inability to attract and/or retain key employees. Hence, organization-level career development initiatives, taking the broader potential career development pathways of boundaryless and traditional career followers into account, would be expected to yield better results in terms of talent attraction and retention.

The career literature underscores the need for TM practices to recognize and celebrate the diversity of the available talent pool (Crowley-Henry and $\mathrm{Al}$ Ariss, 2016). Career research suggests that women and minorities still face a range of barriers to their career success (Al Ariss et al., 2012; Hüttges and Fay, 2013; Tatli et al., 2013). TM practices that recognize the career development needs of women and minorities are likely to help counteract those barriers, allowing for more positive career outcomes for women and minorities as well as positive organizational outcomes (Joshi et al., 2015). For example, Enache et al. (2011) found that women feel more successful in organizations that offer more flexibility. They also conclude that both men and women feel more intrinsic career success when their values match those of the organizations they work for. Huffman et al. (2010) found slow changes towards more gender integration in existing workplaces. Their study has also shown that gender integration is positively correlated with the existence of female top managers. Sealy and Singh (2010) found that organizational 
demography and the existence of senior female role models impacts the career progression for other female managers into top organizational levels. Furthermore, studies have found that organizations need to be sensitive to male bias in selection and career development practices (Siebers, 2009; Hebson and Cox, 2011). In more maledominated occupations and industries senior male mentoring can impact the careers of women positively (Ramaswami et al., 2010). Based on the above discussion of TM and diversity-related career development practices at the organization level, we propose the following:

Proposition 3b. Organizations should proactively provide career plans, opportunities and support to high potential/high performing women and other minority groups under-represented at leadership levels within the organization in order to attract, develop and retain a diverse talent pool across different groups and organization hierarchical levels.

This proposition aligns with the fifth conceptualization of TM as put forward by Crowley-Henry and Al Ariss (2016: 6 (in their Table 1)), where 'TM [is] conceptualized as a broader phenomenon, which integrates individuals, organizations, and society, embracing diversity and equality in societies'. While it is an organization-level initiative, its ramifications are more far-reaching. The relational blurring between levels (as depicted in our Figure 1) is again exemplified here.

\section{The industry and occupational level}

Currie et al. (2006) explain that some industries are more boundaryless than others, such as the film industry, IT, and biotechnology. For example, studies within the film industry (DeFillippi and Arthur, 1998) and pop music (Zwaan et al., 2010) have focused on how careers influence, and are influenced by, project-based work activities and social networks. Similarly, in Littleton et al.'s (2000) research, which highlighted how the boundaryless career was evident in the Silicon Valley and in the independent film-making industry. The shift from one industry to another is also discussed in the literature. In industries that provide less organizational stability and support, people still seek a sense of belonging, and professional networks can provide support when it is not found organizationally. The permeability of levels affecting career pathways and decisions across individual, group/network, organization and industry is apparent (see Figure 1). This movement may not be beneficial to many organizations that are continually losing internal knowledge as employees move from organization to organization (Bird, 1994; Currie et al., 2006). Research has also shown that despite rapid global economic growth, careers in many industries remain stable (Biemann et al., 2011). However, factors such as wage levels, labor intensity, industry growth, and career complexity all vary widely from industry to industry (Feldman and Ng, 2007; Biemann et al., 2011). Furthermore, some industries, such as accounting, have formal career paths laid out for new recruits that include inter-firm movement (DeFillippi and Arthur, 1994).

In Figure 1, we differentiate between the industry-level and the professional/occupational level. We depict the industry level as a broader level within which several organizations may operate. For instance, the accounting industry consists of organizations where accountancy is the core competency of the organizations. On the other hand, at the professional/occupational level which transcends the individual, group/network, organizational, industry, nation and global levels, we refer to those specific occupations/professional careers that may take place in different groups, organizations, and contexts. For instance, an individual working as an accountant in the Finance department of a car manufacturing organization in the automotive industry could transfer his/her skills as an accountant to the Finance department of an information technology organization. In Figure 1 we attempt to encompass the complexity of different levels and contexts in which careers unfold over time and circumstance.

Some career paths do allow for industry-to-industry movement, and those movements are more likely to occur early in individuals' careers. Hwang et al. (2011) conducted a large-scale study of industry level career change among MBA graduates in the USA. Their findings show that perceptions about career growth and advancement opportunities were the strongest predictors of industry shifts following MBA studies.

Boundaries are different depending on occupation as well as industry. Joseph et al. (2012) found that the careers of workers in IT occupations (similar to our accounting example above) are transferrable and can span across industries. These studies suggest that as occupational boundaries become increasingly salient in the contemporary career world, occupational and professional networks are critical tools for career development. $\mathrm{Ng}$ and Feldman (2009), for example, looked at occupational embeddedness, finding strong correlation between occupational embeddedness and organizational and career success factors. From our review of the career literature at the industry and occupational level, we understand that careers in some occupations and industries look very different than careers in others. For example, because of the structure of the film industry, many individuals work as freelancers and are engaged in boundaryless careers (Littleton et al., 2000). Occupations such as accounting tend to lead to more stable careers than, for instance, IT. Thus, we propose the following: 
Proposition 4. Consideration of occupation and industry-specific structures which enable a boundaryless career orientation will positively facilitate TM practices.

To elaborate upon this proposition, we suggest that consideration of the occupation and industry-specific structures that influence careers (i.e., whether or not the respective occupation or the industry allows/encourages boundaryless careers) will enable organizations to better attract, develop and retain talent. In this proposition, a 'best fit' approach to TM practices is recommended, where the industry and occupational context serves as an important indicator of the ease or difficulty of talent attraction, development and retention. A bundling approach to TM practices may be pertinent, where context and best practice in the field coincide in order to create the best conditions to TM fulfilment (attraction, development and retention of key employees in the organization).

\section{The national and global level}

A fifth dimension that we found important in the careers literature is how careers are structured within particular geographic contexts and the way this impacts the management of talents nationally and globally. Themes that emerged include, but are not limited to, the role of culture, history, and more broadly social factors in understanding careers globally, and the impact of international HRM policies and employment relations (Ollier-Malaterre and Foucreault, 2017). Another theme is the international mobility of workers (Crowley-Henry et al., 2016). These topics are discussed below.

Gunz et al. (2011: 1613) highlights the importance of the broad social context as 'the canvas on which work careers are painted'. Historical national/international structures, including specific cultural and economic conditions, are presented as having an important impact on individuals' career stability and possibilities for success (Biemann et al., 2011; Furusawa and Brewster, 2015). Özbilgin and Healy (2004), for example, explain how a history of war and upheaval in the Middle East has shaped present and future career opportunities and perceptions of such opportunities. In ex-colonial countries, ethnicity is seen as important with respect to the career choices and outcomes of individuals (Tatli, 2011). Furthermore, studies on Nigeria (Ituma and Simpson, 2007; Ituma et al., 2011; Okurame and Fabunmi, 2014), Tanzania (Hanchey and Berkelaar, 2015), Sri Lanka (Fernando and Cohen, 2011), the Middle East (Sidani and Al Ariss, 2014), and China (Wong, 2007) are beginning to uncover how distinct political systems and cultures impact career opportunities.

In many countries, careers have changed greatly due to shifts in political, economic, and social conditions (Biemann et al., 2011; Beer et al., 2015). Such trends have led to various conceptualizations of careers such as global careers, hybrid careers, and kaleidoscope careers that recognize the way individuals adapt to changing national and global structures (Shaffer et al., 2012). Cohen and Duberley (2015) found in their study of careers in the public sector that the ideological trends of the 1960s and 1970s in Europe framed the decisions of many of their research participants to enter into public sector work. The political climate, at both national and local levels, also impacted career decisions. Later in their careers, the global financial crisis of the early 2000s changed the nature and structure of their work.

The literature on TM considers the impact of national/international contexts on the attraction, recruitment, development and retention of top talents in organizations. For example, based on data collected from 33 MNCs in eleven countries, Stahl et al. (2011) propose that companies should not simply replicate successful TM practices. Instead, organizations should implement what best fits with their national and international needs. International HRM scholars like Brewster et al. (2008) and Brewster (2004) put forward a 'best fit' approach to managing people internationally. For example, they present 'European perspectives on human resource management', suggesting the existence of institutional and cultural influences that do not conform to business and management globalization trends. According to Khilji et al. (2015), as talent mobility increases, a new cadre of global workers will develop multiple identities, and start taking control of their own careers. This makes it imperative for functional managers and human resource managers to explore ways to effectively interact with these talents and what strategies to use in order to benefit from their expertise, what reward mechanisms to use in order to retain them, and how to plan their careers if they are not willing to slot their careers into strategic corporate plans (Carr et al., 2005). So, organizations operating at a global level should focus on devising mechanisms and policies that promote environments conducive for individual and organizational learning, as it is critical to developing effective talent management outcomes in a global context (Khilji et al., 2015). With this literature in mind, we propose that:

Proposition 5a. Talent Management practices embedded in the national/global context (political, economic and social structures that inform career orientations) will better facilitate the attraction, development and retention of international talents than TM practices that aren't.

Stated alternatively, we propose that within international organizations, talent management practices that are sensitive to a 'best fit' approach in terms of their crafting of career structures will be more successful in 
attracting, developing and retaining international talents across subsidiaries and headquarters than talent management practices that do not.

The boundaryless career concept (DeFillippi and Arthur, 1994) has been used to theorize international careers as boundary crossing endeavors (Shaffer et al., 2012; Dickmann and Cerdin, 2014). Careers scholars have recognized that international mobility is an important topic for understanding contemporary careers (Selmer and Lauring, 2010; Crowley-Henry et al., 2016). Various forms of international mobility have been studied. Corporate expatriation is the form of international mobility that has attracted the most attention for management scholars engaging in empirical studies on international careers. The topic of expatriate career success is often linked to family matters. For example, Cole (2011) shows that the non-adjustment of an expatriate's spouse to an international setting can constitute a barrier in pursuing the international assignment. Therefore, to reduce expatriate career failures and improve company performance, organizations need to increasingly support expatriates' spouses in matters such as their employment and settling in the host country. Based on a study of 26 Indian expatriates in Japan, Agullo and Egawa (2009) suggest that understanding professional and personal priorities and values are essential in planning the careers of expatriates. At the organizational level, Mezias and Scandura (2005) argue that mentoring has a positive impact on international careers. These same authors suggest that mentoring for expatriates can assist their adjustment and career development at the stages of pre-departure, expatriation, and repatriation. Here again, the overlap and permeability between levels in our multilevel framework (see Figure 1) is apparent; in the above example, mentoring across organizational, national and global levels.

Linked to this, the forms of capitals that are mobilized by expatriates during and after their international mobility are extensively discussed in the literature (know-how, know-whom, and know-why career capital, DeFillippi and Arthur, 1994). For example, Doherty and Dickmann (2009) suggest that organizations lack planning into how they can use the capital accumulated by repatriates. In terms of job security, migrants are often represented as having fewer career choices and less positive outcomes than the nationals of a host country. For example, Hakak et al. (2010) point to challenges that Latin American MBAs in Canada experience when integrating into the job market. Despite their strong educational backgrounds, participants perceived several challenges to their success in the Canadian workplace, specifically language barriers, lack of networks, cultural differences, and discrimination. Skilled international workers are known to enhance the competitive advantages of their employers (Cerdin et al., 2014). However, there is lack of research on the TM of international skilled workers (Al Ariss et al., 2014; Crowley-Henry and Al Ariss, 2016). This discussion leads to our final proposition linking TM to contemporary career orientations at the national/global level:

Proposition 5b. Organizations that take into account and provide tailored career development support (such as language classes, cross-cultural classes; support in the initial household administration requirements when relocating to another country; family adjustment support) will be better able to leverage the international talent pool that they have attracted and will be able to retain, thanks to such tailored career development TM practices.

Similar to Proposition 4 above, our Proposition suggests a 'best fit' tailored TM approach for the internationally mobile talent. Given the specific barriers (e.g., language, regulatory), challenges (e.g., acculturation, family adjustment), and benefits (e.g., diverse knowledge, skills and abilities) of the international talent pool, a bundling of best practices relevant for the attraction, development and retention of key international employees, varying depending on home and host country norms, is recommended.

\section{Conclusions and suggested future research directions}

In this paper, we have discussed how careers are influenced by and across different levels (see Figure 1), and how an understanding of this will better inform TM practices, particularly at the organizational level. Furthermore, we have shown how considering TM practices through a career lens, in particular the traditional and boundaryless career lenses, could help theorize $\mathrm{TM}$, and also could support improved TM practices (see Proposition 1). By putting forward researchable propositions (see Table 2 which summarizes all of the propositions), our discussion contributes to the career literature by positioning $\mathrm{TM}$ as an academic field which can be better understood when linked to career theory and research. Underlying our arguments are the assumptions that organizations are interested in maximizing the talents of their employees for competitive advantage (Cascio and Boudreau, 2016; Crowley-Henry and Al Ariss, 2016), and that employees' career concerns should be considered when developing TM policies and practices (where the overall TM objective is the attraction, development and retention of key employees, Collings and Mellahi, 2009). Our literature review reveals that TM, as a growing HRM topic, has much to consider regarding how career influences across different levels affect the attraction, development and retention of talented 
Table 2 Propositions developed from multi-level career literature which could better inform TM practices

\begin{tabular}{|c|c|}
\hline Proposition 1. & $\begin{array}{l}\text { Talent management practices should be flexibly tailored (e.g. moderating between intrinsic and extrinsic rewards) } \\
\text { to traditional and boundaryless career orientations, cognizant that individual career orientations can differ and } \\
\text { potentially change over time. }\end{array}$ \\
\hline Proposition . & $\begin{array}{l}\text { TM practices should leverage on the formal and informal internal group association of its employees as it } \\
\text { facilitates the information-gathering and socialization of prospective and existing 'talent', and de facto, in } \\
\text { attracting, developing and retaining talent to and within organizations. }\end{array}$ \\
\hline Proposition . & $\begin{array}{l}\text { Proposition. TM practices should leverage on the formal and informal external network association of its } \\
\text { employees as it facilitates the expectations and comparison processing of organizational contexts of prospective } \\
\text { and existing 'talent', and de facto, in attracting, developing and retaining talent to, within and across } \\
\text { organizations. }\end{array}$ \\
\hline Proposition . & $\begin{array}{l}\text { Organization-level career development plans, opportunities and supports strategically tailored for high potential } \\
\text { employees demonstrating boundaryless (e.g. lateral, vertical or international mobility preferences) and traditional } \\
\text { (e.g. vertical mobility preferences) career orientations will reduce turn-over intentions and thereby facilitate the } \\
\text { performance development and retention of talent within the organization. }\end{array}$ \\
\hline Proposition . & $\begin{array}{l}\text { Organizations should proactively provide career plans, opportunities and support to high potential/high performing } \\
\text { women and other minority groups under-represented at leadership levels within the organization in order to attract, } \\
\text { develop and retain a diverse talent pool across different groups and organization hierarchical levels. }\end{array}$ \\
\hline Proposition 4. & $\begin{array}{l}\text { Consideration of occupation and industry-specific structures which enable a boundaryless career orientation will } \\
\text { positively facilitate TM practices. }\end{array}$ \\
\hline Proposition . & $\begin{array}{l}\text { Talent management practices embedded in the national/global context (political, economic and social structures that } \\
\text { inform career orientations) will better facilitate the attraction, development and retention of international talents } \\
\text { than TM practices } \\
\text { that aren't. }\end{array}$ \\
\hline Proposition . & $\begin{array}{l}\text { Organizations that take into account and provide tailored career development support (such as language classes, } \\
\text { cross-cultural classes; support in the initial household administration requirements when relocating to another } \\
\text { country; family adjustment support) will be better able to leverage the international talent pool that they have } \\
\text { attracted and will be able to retain, thanks to such tailored career development TM practices. }\end{array}$ \\
\hline
\end{tabular}

employees by organizations. The propositions we put forward could serve as concrete foundations to further develop academic research on TM in organizations.

For instance, we found that there is a significant lack of research on career development at the group/collective level. This is critical as groups such as communities of practice and networks external to organizational contexts are increasingly important for career success and mobility (Currie et al., 2006; Oh et al., 2006) and they interplay with larger patterns of family, and economic strands of individual lives (Lee et al., 2011). Thus, as groups generate critical social capital resources, group cohesiveness and success is improved, and those resources benefit individuals and their careers, organizations, and industries, as well as broader contexts. Future research on TM could consider the way collective talents, embodied by groups such as professional groups and virtual social networks, might facilitate or hinder relationships between careers and industry context. Companies like Airbus are moving in such a direction where talents become less of an individual and more of a collective matter. In this sense, the collective refers to all companies working in the aerospace industry in Europe, which would benefit from exchanging their knowledge through their talents. This would allow the company to benefit from and bring benefit to the whole European aerospace industry. We encompassed this in our group/network level propositions (Propositions and ), recommending that TM practices consider the role of formal and informal internal group and external network structures in the attraction, development and retention of talent to, within and across organizations. We furthered this in our fourth proposition, underlining the occupation and industry-specific structures (and whether or not these are supportive of a boundaryless career orientation), which influence the attraction, development and turnover/retention intentions of recognized talented employees.

We also found that although boundaryless careers are common, organizations maintain a central role in determining career paths. TM practices need therefore to be framed and adapted to accommodate different individual career motivations and pathways (our individual-level proposition, Proposition 1 and our organization-level Proposition ). Furthermore, while careers often entail movement from organization to organization, there are still boundaries that exist that may be particularly salient for women, minorities, and recent immigrants (our third propositions at the organizational level, specifically Proposition ; and our Proposition ). Relationships across groups and networks that can enable or constrain individual careers are being developed outside of organizations. We foresee that in future studies, TM scholarship centered on boundaryless careers will benefit if it focuses on revealing existing boundaries (such as those discussed in this paper), 
uncovering how precisely they operate, who they impact most (Inkson et al., 2012), and how organizations can better manage them (e.g., our Proposition ).

TM in Western countries and organizational contexts suppose that individuals invest their time, energy, and career capital in order to accomplish subjective career success (Hall and Chandler, 2005). Nevertheless, we now know that people increasingly prefer work-life balance over power, prestige, money, and lateral advancement in their careers (Mayrhofer et al., 2008; Ezzedeen and Ritchey, 2009). However, we suspect that individuals' relationships to their careers vary greatly depending on national context (Ituma and Simpson, 2009; Tung, 2016). Therefore, TM research across cultural clusters is required to confirm this issue. Future TM studies would benefit from comparing how individuals perceive their careers across different countries (our Propositions and ). Recent changes to the global economy and organizational structures have clearly led to changes in careers (Beer et al., 2015). However, the extent of these changes and whether they will ultimately prove to be beneficial to individuals is yet to be determined.

This paper does have several limitations, that ultimately open doors for other avenues of research. First, we have presented the influencing career structures separately in our paper, but we acknowledge that these are intricately woven together in practice. We have attempted to incorporate this in our discussion and in Figure 1. Second, while many of our propositions imply a high level of individual career agency, we do recognize that organizational restructuring often includes downsizing and certainly impacts career structures. More research is needed to understand how TM practices could include strong contingency plans for times when downsizing is considered necessary. Third, this paper is conceptual, developed from existing research and literature. Further research is needed to fully understand and empirically establish the connections among TM and career structures. The research propositions developed and shared in this paper provide future potential research directions in this domain.

The research directions that we indicate in our research propositions show the need for a greater understanding of how the individual, group/network, organization, industry/occupation, and national/global structures within which careers unfold shape TM in a changing global economy. Finally, based on our propositions, future TM studies could focus on how the different career structures intersect within TM patterns. For example, as organizations engage in TM activities, how do they take into account career development of their talents in the context of the occupations and industries to which they belong? How is the triad of talent attraction, development and retention - the fundamental attributes of TM - inter-connected in theory and practice? Furthermore, how do the career activities of individuals belonging to groups, organizations, and industries shape broad national and economic contexts of TM and vice versa?

\section{Acknowledgments}

The authors would like to thank the editors, anonymous reviewers, and Dr Jayasmita Rath for their feedback on earlier versions of this paper.

\section{References}

Agullo, B. and M. Egawa, 2009, "International careers of Indian workers in Tokyo: Examination and future directions". Career Development International, 14: 148-168.

Al Ariss, A., W. Cascio and J. Paauwe, 2014, "Talent management: Current theories and future research directions". Journal of World Business, 49: 173-179.

Al Ariss, A. and J. Syed, 2011, "Capital mobilization of skilled migrants: A relational perspective". British Journal of Management, 22: 286-304.

Al Ariss, A., J. Vassilopoulou, M. Özbilgin and A. Game, 2012, "Understanding career experiences of skilled minority ethnic workers in France and Germany". The International Journal of Human Resource Management, 24: 1236-1256.

Allen, T., J. Russell and S. Maetzke, 1997, "Formal peer mentoring: Factors related to protégés' satisfaction and willingness to mentor others". Group and Organization Management, 22: 488-507.

Argyris, C., 1960. Understanding organizational behaviour. Homewood, IL: Dorsey Press.

Arthur, M., 1994, "The boundaryless career: A new perspective for organizational inquiry". Journal of Organizational Behavior, 15: 295-306.

Arthur, M. and D. Rousseau, 1996. "Introduction: The boundaryless career as a new employment principle". In Arthur M. and D. Rousseau (eds.), The boundaryless career: A new employment principle for a new organizational Era. New York: Oxford University Press, pp. 3-20.

Bagdadli, S., L. Solari, A. Usai and A. Grandori, 2003, "The emergence of career boundaries in unbounded industries: Career odysseys in the Italian New Economy". International Journal of Human Resource Management, 14: 788-808.

Baruch, Y. and Y. Vardi, 2016, "A fresh look at the dark side of contemporary careers: Toward a realistic discourse". British Journal of Management, 27: 355-372.

Beer, M., P. Boselie and C. Brewster, 2015, "Back to the future: Implications for the field of HRM of the multistakeholder perspective proposed 30 years ago". Human Resource Management, 54: 427-438.

Biemann, T., A. Fasang and D. Grunow, 2011, "Do economic globalization and industry growth destabilize careers? An analysis of career complexity and career patterns over time". Organization Studies, 32: 1639-1663. 
Billett, S., 2001, "Learning through work: Workplace affordances and individual engagement". Journal of Workplace Learning, 13: 209-214.

Bird, A., 1994, "Careers as repositories of knowledge: A new perspective on boundaryless careers". Journal of Organizational Behavior, 15: 325-344.

Bozionelos, N., 2004, "The relationship between disposition and career success: A British study". Journal of Occupational and Organizational Psychology, 77: 403-420.

Brewster, C., 1999. "Different paradigms in strategic HRM: Questions raised by comparative research". In Wright P., J. B. Dyer and G. Milkovich (eds.), Research in Personnel and HRM. Greenwich. CT: JAI Press, pp. 213-238.

Brewster, C., 2004, "European perspectives on human resource management". Human Resource Management Review, 14: 365-382.

Brewster, C. and C. Bennett, 2010, "Perceptions of business cultures in Eastern Europe and their implications for international HRM". The International Journal of Human Resource Management, 21: 2568-2588.

Brewster, C., G. Wood and M. Brookes, 2008, "Similarity, isomorphism or duality? Recent survey evidence on the human resource management policies of multinational corporations". British Journal of Management, 19: 320-342.

Carr, S. C., K. Inkson and K. Thorn, 2005, "From global careers to talent flow: Reinterpreting 'brain drain'". Journal of World Business, 40: 386-398.

Cascio, W. and J. Boudreau, 2016, "The search for global competence: From international HR to talent management". Journal of World Business, 51: 103-114.

Cerdin, J.-- L. and C. Brewster, 2014, "Talent management and expatriation: Bridging two streams of research and practice". Journal of World Business, 49: 245-252.

Cerdin, J.-. L., M. Diné and C. Brewster, 2014, "Qualified immigrants' success: Exploring the motivation to migrate and to integrate". Journal of International Business Studies, 45: 151-168.

Chang, J., 2005, "Casting a net". Sales and Marketing Management, 157: 28-32.

Chen, Z., J. Veiga and G. Powell, 2011, "A survival analysis of the impact of boundary crossings on managerial career advancement up to midcareer". Journal of Vocational Behavior, 79: 230-240.

Chiaburu, D. S. and D. A. Harrison, 2008, "Do peers make the place? Conceptual synthesis and meta-analysis of coworker effects on perceptions, attitudes, OCBs, and performance". Journal of Applied Psychology, 93: 1082-1103.

Claussen, J., T. Grohsjean, J. Luger and G. Probst, 2014, "Talent management and career development: What it takes to get promoted". Journal of World Business, 49: 236-244.

Clinton, M., C. Bernhard-Oettel, T. Rigotti and J. de Jong, 2011, "Expanding the temporal context of research on nonpermanent work previous experience, duration of and time remaining on contracts and employment continuity expectations". Career Development International, 16: 114-139.

Cohen, L. and J. Duberley, 2015, "Three faces of context and their implications for career: A study of public sector careers cut short". Journal of Vocational Behavior, 91: 189-202.

Cole, N., 2011, "Managing global talent: Solving the spousal adjustment problem". International Journal of Human Resource Management, 22: 1504-1530.
Collings, D. and K. Mellahi, 2009, "Strategic talent management: A review and research agenda". Human Resource Management Review, 19: 301-313.

Collings, D. G., 2014, "Integrating global mobility and global talent management: Exploring the challenges and strategic opportunities". Journal of World Business, 49: 253-261.

Converse, P., J. Pathak, A. DePaul-Haddock, T. Gotlib and M. Merbedone, 2012, "Controlling your environment and yourself: Implications for career success". Journal of Vocational Behavior, 80: 148-159.

Crowley-Henry, M. and A. Al Ariss, 2016, "Talent management of skilled migrants: Propositions and an agenda for future research". International Journal of Human Resource Management, 1-27 https://doi.org/10.1080/09585192.2016. 1262889 [Online First].

Crowley-Henry, M., E. O'Connor and A. Al Ariss, 2016, 'Portrayal of skilled migrants' careers in business and management studies: A review of the literature and future research agenda". European Management Review, 1-20 https://doi.org/10.1002/emre.12072 [Online First].

Currie, G., S. Tempest and K. Starkey, 2006, "New careers for old? Organizational and individual responses to changing boundaries". The International Journal of Human Resource Management, 17: 755-755.

Dansky, K., 1996, "The effect of group mentoring on career outcomes". Group and Organization Management, 21: 5-21.

Dany, F., 2003, “'Free actors' and organizations: Critical remarks about the new career literature, based on French insights". International Journal of Human Resource Management, 14: 821-838.

Dawley, D., M. Andrews and N. Bucklew, 2010, "Enhancing the ties that bind: Mentoring as a moderator". Career Development International, 15: 259-278.

De Boeck, G., Meyers, M. C. and N. Dries, 2018, "Employee reactions to talent management: Assumptions versus evidence". Journal of Organizational Behavior, 39: 199-213 https://doi.org/10.1002/job.2254 [Online First].

De Vos, A. and N. Dries, 2013, "Applying a talent management lens to career management: The role of human capital composition and continuity". The International Journal of Human Resource Management, 24: 1816-1831.

DeFillippi, R. and M. Arthur, 1994, "The boundaryless career: A competency perspective". Journal of Organizational Behavior, 15: $307-324$.

DeFillippi, R. and M. Arthur, 1998, "Paradox in project-based enterprise: The case of film making". California Management Review, 40: 125-139.

Delery, J. and H. Doty, 1996, "Modes of theorizing in strategic human resource management: Tests of universalistic, contingency, and configurational performance predictions". Academy of Management Journal, 39: 802-835.

Dickmann, M., C. Brewster and P. Sparrow, 2016. International human resource management: Contemporary HR issues in Europe. New York: Routledge.

Dickmann, M. and J.-L. Cerdin, 2014, "Boundaryless career drivers - exploring macro-contextual factors in location decisions". Journal of Global Mobility, 2: 26-52.

Doherty, N. and M. Dickmann, 2009, "Exposing the symbolic capital of international assignments". International Journal of Human Resource Management, 20: 301-320. 
Dries, N., 2013a, "Talent management, from phenomenon to theory: Introduction to the special issue". Human Resource Management Review, 23: 267-271.

Dries, N., 2013b, "The psychology of talent management: A review and research agenda". Human Resource Management Review, 23: 272-285.

Dries, N. and R. Pepermans, 2008, “'Real' high-potential careers: an empirical study into the perspectives of organisations and high potentials". Personnel Review, 37: 85-108.

Dries, N., F. Van Acker and M. Verbruggen, 2012, "How 'boundaryless' are the careers of high potentials, key experts and average performers?" Journal of Vocational Behavior, 81: 271-278.

Eddleston, K., 2009, "The effects of social comparisons on managerial career satisfaction and turnover intentions". Career Development International, 14: 87-110.

Ellström, P.-E., 2001, "Integrating learning and work: Problems and prospects". Human Resource Development Quarterly, 12: 421-436.

Enache, M., J. Sallán, P. Simo and V. Fernandez, 2011, "Career attitudes and subjective career success: Tackling gender differences". Gender in Management, 26: 234-250.

Enache, M., J. Sallán, P. Simo and V. Fernandez, 2013, "Organizational commitment, within a contemporary career context”. International Journal of Manpower, 34: 880-898.

Ezzedeen, S. and K. Ritchey, 2009, "Career advancement and family balance strategies of executive women". Gender in Management, 24: 388-411.

Farndale, E., A. Pai, P. Sparrow and H. Scullion, 2014, "Balancing individual and organizational goals in global talent management: A mutual-benefits perspective". Journal of World Business, 49: 204-214.

Feldman, D. and T. Ng, 2007, "Careers: Mobility, embeddedness, and success". Journal of Management, 33: 350-377.

Fernando, W. and L. Cohen, 2011, "Exploring the interplay between gender, organizational context and career: A Sri Lankan perspective". Career Development International, 16: 553-571.

Festing, M. and L. Schäfer, 2014, "Generational challenges to talent management: A framework for talent retention based on the psychological-contract perspective". Journal of World Business, 49: 262-271.

Forret, M. L. and T. W. Dougherty, 2004, "Networking behaviors and career outcomes: Differences for men and women?" Journal of Organizational Behavior, 25: 419-437.

Friedman, R., M. Kane and D. Cornfield, 1998, "Social support and career optimism: Examining the effectiveness of network groups among black managers". Human Relations, 51: 1155-1177.

Fuller, B. and L. Marler, 2009, "Change driven by nature: A meta-analytic review of the proactive personality literature". Journal of Vocational Behavior, 75: 329-345.

Furusawa, M. and C. Brewster, 2015, "The bi-cultural option for global talent management: The Japanese/Brazilian Nikkeijin example". Journal of World Business, 50: 133-143.

Gallardo-Gallardo, E., N. Dries and T. González-Cruz, 2013, "What is the meaning of 'talent' in the world of work?" Human Resource Management Review, 23: 290-300.
Gallardo-Gallardo, E., S. Nijs, N. Dries and P. Gallo, 2015, "Towards an understanding of talent management as a phenomenon-driven field using bibliometric and content analysis". Human Resource Management Review, 25: 264-279.

Gallardo-Gallardo, E. and M. Thunnissen, 2016, "Standing on the shoulders of giants? A critical review of empirical talent management research". Employee Relations, 38: 31-56.

Gelens, J., N. Dries, J. Hofmans and R. Pepermans, 2013, "The role of perceived organizational justice in shaping the outcomes of talent management: A research agenda". Human Resource Management Review, 23: 341-353.

Gelens, J., J. Hofmans, N. Dries and R. Pepermans, 2014, "Talent management and organisational justice: employee reactions to high potential identification". Human Resource Management Journal, 4: 159-175.

Goldman, A., 2011, "Demagogue to dialogue: An alternative to toxic leadership in corporate downsizings". Organizational Dynamics, 40: 235-241.

Grote, G. and D. Hall, 2013, "Reference groups: A missing link in career studies". Journal of Vocational Behavior, 83: 265-279.

Gunz, H., W. Mayrhofer and P. Tolbert, 2011, "Career as a social and political phenomenon in the globalized economy". Organization Studies, 32: 1613-1620.

Hakak, L., I. Holzinger and J. Zikic, 2010, "Barriers and paths to success Latin American MBAs' views of employment in Canada". Journal of Managerial Psychology, 25: 159-176.

Hall, D. and D. Chandler, 2005, "Psychological success: When the career is a calling". Journal of Organizational Behavior, 26: $155-176$.

Hanchey, J. and B. Berkelaar, 2015, "Context matters: examining discourses of career success in Tanzania". Management Communication Quarterly, 29: 411-439.

Hassard, J., J. Morris and L. McCann, 2012, “"My brilliant career'? New organizational forms and changing managerial careers in Japan, the UK, and USA". Journal of Management Studies, 49: 571-599.

Hay Group, 2001, "The retention dilemma: Why productive workers leave - Seven suggestions for keeping them". [Brochure]. Philadelphia, PA: Hay Group.

Hebson, G. and A. Cox, 2011, "The gendered implications of corporate value change". Gender Work and Organization, 18: 182-201.

Huffman, M., P. Cohen and J. Pearlman, 2010, "Engendering change: Organizational dynamics and workplace gender desegregation, 1975-2005". Administrative Science Quarterly, 55: 255-277.

Hüttges, A. and D. Fay, 2013, "Call for papers: 'Gender influences on career development'". Journal of Personnel Psychology, 12: 57-57.

Hwang, A., R. Bento and B. Arbaugh, 2011, "Post-MBA industry shifts: An investigation of career, educational and demographic factors". Career Development International, 16: 592-615.

Iles, P., D. Preece and X. Chuai, 2010, "Talent management as a management fashion in HRD: Towards a research agenda". Human Resource Development International, 13: 125-145.

Inkson, K., H. Gunz, S. Ganesh and J. Roper, 2012, "Boundaryless careers: Bringing back boundaries". Organization Studies, 33: 323-340. 
Ituma, A. and R. Simpson, 2007, "Moving beyond Schein's typology: Individual career anchors in the context of Nigeria". Personnel Review, 36: 978-995.

Ituma, A. and R. Simpson, 2009, “The 'boundaryless' career and career boundaries: Applying an institutionalist perspective to ICT workers in the context of Nigeria". Human Relations, 62 : 727-761.

Ituma, A., R. Simpson, F. Ovadje, N. Cornelius and C. Mordi, 2011, 'Four 'domains' of career success: How managers in Nigeria evaluate career outcomes". International Journal of Human Resource Management, 22: 3638-3660.

Joseph, D., W. Boh, S. Ang and S. Slaughter, 2012, "The career paths less (or more) traveled: A sequence analysis of it career histories, mobility patterns, and career success". MIS Quarterly, 36: 427-452.

Joshi, A., J. Son and H. Roh, 2015, "When can women close the gap? A meta-analytic test of sex differences in performance and rewards". Academy of Management Journal, 58: 1516-1545.

Judge, T. and J. Kammeyer-Mueller, 2011, "Implications of core self-evaluations for a changing organizational context". Human Resource Management Review, 21: 331-341.

Kessels, J. W. M. and R. F. Poell, 2004, “Andragogy and social capital theory: The implications for human resource development". Advances in Developing Human Resources, 10: $1-12$.

Khapova, S. and M. Arthur, 2011, "Interdisciplinary approaches to contemporary career studies". Human Relations, 64: 3-17.

Khilji, S. E., I. Tarique and R. S. Schuler, 2015, "Incorporating the macro view in global talent management". Human Resource Management Review, 25: 236-248.

Koberg, C., W. Boss, D. Chappell and R. Ringer, 1994, "Correlates and consequences of protege mentoring in a large hospital". Group and Organization Management, 19: 219-239.

Lawrence, B., 2006, “Organizational reference groups: A missing perspective on social context". Organization Science, 17: 80-100.

Lawrence, B., 2011, "The Hughes Award: Who is they? Inquiries into how individuals construe social context". Human Relations, 64: 749-773.

Lee, M., E. Kossek, D. T. Hall and J.-B. Litrico, 2011, "Entangled strands: A process perspective on the evolution of careers in the context of personal, family, work, and community life". Human Relations, 64: 1531-1553.

Levinson, H., C. R. Price, K. J. Munden, H. J. Mandl and C. M. Solley, 1962. Men, management and mental health. Cambridge, MA: Harvard University Press.

Lewis, R. and R. Heckman, 2006, "Talent management: A critical review". Human Resource Management Review, 16: 139-154.

Littleton, S. M., M. B. Arthur and D. M. Rousseau, 2000. "The future of boundaryless careers". In Collin A. and R. A. Young (eds.), The future of career. Cambridge: Cambridge University Press, pp. 101-114.

Lyons, S., L. Schweitzer, E. Ng and L. Kuron, 2012, "Comparing apples to apples: A qualitative investigation of career mobility patterns across four generations". Career Development International, 17: 333-357.

Manolopoulos, D., P. Dimitratos and E. Sofikitis, 2011, "Predictors of career preferences of MNC knowledge professionals". Personnel Review, 40: 466-484.
Mayrhofer, W., M. Meyer, M. Schiffinger and A. Schmidt, 2008, "The influence of family responsibilities, career fields and gender on career success". Journal of Managerial Psychology, 23: 292-323.

McDonnell, A., D. Collings, K. Mellahi and R. Schuler, 2017, "Talent management: A systematic review and future prospects". European Journal of International Management, 11: 86-128.

Meyers, C., M. van Woerkom and N. Dries, 2013, "Talent innate or acquired? Theoretical considerations and their implications for talent management". Human Resource Management Review, 23: 305-321.

Mezias, J. and T. Scandura, 2005, “A needs-driven approach to expatriate adjustment and career development: A multiple mentoring perspective". Journal of International Business Studies, 36: 519-538.

Michaels, E., H. Handfield-Jones and B. Axelrod, 2001. The war for talent. Boston, MA: Harvard Business Press

Ng, T. and D. Feldman, 2009, "Occupational embeddedness and job performance". Journal of Organizational Behavior, 30: 863-891.

O'Connor, E. P. and M. Crowley-Henry, 2017, "Exploring the relationship between exclusive talent management, perceived organizational justice and employee engagement: Bridging the literature". Journal of Business Ethics, 1-17 https://doi.org/ 10.1007/s10551-017-3543-1 [Online First].

Oh, H., G. Labianca and M.-H. Chung, 2006, "A multilevel model of group social capital". Academy of Management Review, 31: 569-582.

Okurame, D. and R. Fabunmi, 2014, "Protean and boundaryless careers: Exploring the role of mentoring and gender in the context of a major African country". Career Development International, 19: 73-100.

Ollier-Malaterre, A. and A. Foucreault, 2017, "Cross-national work-life research: Cultural and structural impacts for individuals and organizations". Journal of Management, 43: 111-136. https://doi.org/10.1177/0149206316655873 [Online First].

Özbilgin, M. and G. Healy, 2004, "The gendered nature of career development of university professors: The case of Turkey". Journal of Vocational Behavior, 64: 358-371.

Patton, W., C. Doherty and P. Shield, 2014, "The extended context of career: Families negotiating education and career decisions". Australian Journal of Career Development, 23: 69-78.

Poell, R. F. and F. J. Van der Krogt, 2002. "Using social networks in organisations to facilitate individual development". In Pearn M. (ed.), Handbook of individual development. London: Wiley, pp., 285-304.

Ramaswami, A., G. Dreher, R. Bretz and C. Wiethoff, 2010, "Gender, mentoring, and career success: The importance of organizational context”. Personnel Psychology, 63: 385-405.

Reiche, S., 2009, "To quit or not to quit: Organizational determinants of voluntary turnover in MNC subsidiaries in Singapore". International Journal of Human Resource Management, 20: 1362-1380.

Reiche, S., M. Kraimer and A.-W. Harzing, 2011, "Why do international assignees stay? An organizational embeddedness perspective". Journal of International Business Studies, 42: 521-544.

Reitman, F. and J. Schneer, 2005, "The long-term negative impacts of managerial career interruptions: A longitudinal 
study of men and women MBAs". Group and Organization Management, 30: 243-262.

Sealy, R. and V. Singh, 2010, "The importance of role models and demographic context for senior women's work identity development". International Journal of Management Reviews, 12: 284-300.

Selmer, J. and J. Lauring, 2010, "Self-initiated academic expatriates: Inherent demographics and reasons to expatriate". European Management Review, 7: 169-179.

Shaffer, M., M. Kraimer, Y.-P. Chen and M. Bolino, 2012, "Choices, challenges, and career consequences of global work experiences: A review and future agenda". Journal of Management, 38: 1282-1327.

Sidani, Y. and A. Al Ariss, 2014, "Institutional and corporate drivers of global talent management: Evidence from the Arab Gulf region". Journal of World Business, 49: 215-224.

Siebers, H., 2009, “(Post) bureaucratic organizational practices and the production of racioethnic inequality at work". Journal of Management and Organization, 15: 62-81.

Stahl, G., I. Björkman, E. Farndale, S. Morris, J. Paauwe, P. Stiles, et al., 2011, "Six principles of effective global talent management". MIT Sloan Management Review, 53: 25-42.

Steward, M. D., B. A. Walker, M. D. Hutt and A. Kumar, 2010, "The coordination strategies of high-performing salespeople: Internal working relationships that drive success". Journal of the Academy of Marketing Science, 38: 550-566.

Storberg, J., 2002, "The evolution of capital theory: A critique of a theory of social capital and implications for HRD". Human Resource Development Review, 1: 468-499.

Streumer, J., 2006. Work-related Learning. Dordrecht: Springer.

Sullivan, S. and Y. Baruch, 2009, "Advances in career theory and reseach: A critical review and agenda for future exploration". Journal of Management, 35: 1542-1571.

Sullivan, S. E. and R. Emerson, 2000, "Recommendations for successfully navigating the boundaryless career: from theory to practice". Bowling Green State University, Bowling Green. Paper presented at the Academy of Management (2000) Annual Conference, Chicago.

Tatli, A., 2011, "A multi-layered exploration of the diversity management field: Diversity discourses, practices and practitioners in the UK". British Journal of Management, 22: 238-253.
Tatli, A., J. Vassilopoulou and M. Özbilgin, 2013, “An unrequited affinity between talent shortages and untapped female potential: The relevance of gender quotas for talent management in high growth potential economies of the Asia Pacific region”. International Business Review, 22: 539-553.

Thornhill, A. and M. Saunders, 1998, "The meanings, consequences and implications of the management of downsizing and redundancy: A review". Personnel Review, 27: 271-295.

Thunnissen, M., P. Boselie and B. Fruytier, 2013, "A review of talent management: 'Infancy or adolescence?". The International Journal of Human Resource Management, 24: 1744-1761.

Tjepkema, S., 2003, The learning infrastructure of self-managing work teams. PhD thesis, Twente University.

Tung, R., 2016, "New perspectives on human resource management in a global context". Journal of World Business, 51: 142-152.

Vaiman, V. and D. G. Collings, 2013, "Talent management: advancing the field". The International Journal of Human Resource Management, 24: 1737-1743.

Walsh, K., S. Fleming and C. Enz, 2016, "Give and you shall receive: Investing in the careers of women professionals". Career Development International, 21: 193-211.

Wolff, H.-. G. and K. Moser, 2009, "Effects of networking on career success: A longitudinal study". The Journal of applied psychology, 94: 196-206.

Wong, A., 2007, "Making career choice: A study of Chinese managers". Human Relations, 60: 1211-1233.

Wright, P. M. and J. H. Nishii, 2006, "Strategic HRM and organizational behavior: Integrating multiple levels of analysis”. CAHRS Working Paper \#06-05. Available from http://digitalcommons.ilr.cornell.edu/cahrswp/405/ (accessed June 3, 2018).

Wright, P. M. and S. A. Snell, 1998, “Toward a unifying framework for exploring fit and flexibility in strategic human resource management". The Academy of Management Review, 24: $31-48$.

Zwaan, K., T. ter Bogt and Q. Raaijmakers, 2010, "Career trajectories of Dutch pop musicians: A longitudinal study". Journal of Vocational Behavior, 77: 10-20. 